\title{
Rethinking Cyberreligion?
}

\author{
Teens, Religion and the Internet in Sweden ${ }^{1}$
}

\author{
Mia LÖVHeIM
}

\begin{abstract}
Since the coming of the Internet scholars have been discussing its implications for the future of religion. With its high levels of Internet use and low levels of religious practice Sweden represents an interesting case for studying these issues. This article presents findings from the first online survey of Swedish teenager's use of the Internet for religious purposes, conducted at one of the largest social networking sites LunarStorm. The results show that more young people seem to come into contact with religion via the Internet than through local religious communities. However, the findings also challenge several early expectations about the Internet as a new arena for religion in contemporary society. Thus the article initiates a critical discussion of what conclusions may be drawn from these results, and where future research on young people, religion and the Internet should be directed.
\end{abstract}

Keywords: Internet, social networking sites, religious change, teenagers, Sweden

\section{Introduction}

In the summer of 2007, the largest Christian daily paper in Sweden, Dagen, published an article entitled 'Religion on the Net - challenge and possibility'. The opening part of the article reads: "The number of churchgoers in Sweden has been steadily dropping during recent years. At the same time, many people turn to the newly opened religious Internet sites. This implies a challenge for churches and denominations that are trying to reach new groups." The article is a good illustration of expectations that have remained a salient theme in discussions about the impact of the Internet on religion since the early 1990s. Research on religion and the Internet has been carried out for almost a decade (Hadden \& Cowan 2000, Dawson \& Cowan 2004, Højsgaard \& Warburg 2005). Religious organizations have been an important force behind the interest in studying these issues. As the article in Dagen shows, the Internet is framed as a crucial issue for the future of these organizations, and young people are seen as a key group in this respect. Churches and denominations develop their own websites and provide services such as broadcasting services online, discussion groups and possibilities to chat with or post questions and prayer requests to religious leaders. Furthermore, the fact that the majority of studies published so far focus on Christianity ( $c f$. Campbell 2006:12) suggests that the interests of religious organizations have also played a role in shaping the aims of the research. The present study takes place within the scope of a research program on religion in young people's lives initiated by the Church of Sweden. The aim of the article, however, is to discuss the findings from a perspective that calls for 
reconsideration of the expectations of the Internet as a new arena for exploring religion, as expressed in the article cited above, and to initiate a discussion on what this implies for future research in the area.

\section{Religion on the Internet: Indications in Previous Research}

In 2004, the Pew Internet \& American Life Project in collaboration with Stewart M Hoover and Lynn Schofield Clark at the Center for Research on Media, Religion and Culture, University of Colorado at Boulder, published a frequently cited report called "Faith online" 2 . The findings of their study show that 64 percent had used the Internet for religious purposes. This figure indicates that the Internet is a significant context for religion among American Internet users. However, their findings also show that their use of the Internet may not correspond to the expectations expressed by religious organizations: The majority of users were already members of local religious organizations, and the most frequent activities were sending and receiving e-mail with religious or spiritual content, exchanging online greeting cards related to religious holidays or reading news accounts of religious events and affairs (Hoover, Clark \& Rainie 2004:i) ${ }^{3}$. For these reasons, the report "Faith online" provides an interesting point of departure for the present study. Do these findings correspond to the situation in another national context, and especially among young people?

The religious situation in Sweden differs in several ways from the American context. A national study of youth and religion in the United States showed that three quarters of American teenagers between 13-17 years of age consider themselves Christians (Smith 2005:31), and almost 60 percent attend services at least once a month. In Sweden, almost 80 percent of the population aged between 16-24 years are members of the former official national church, Church of Sweden. However, not more than a few percent of these attend services as often as once a month. Almost 36 percent state that they never visit the church ${ }^{4}$. In international comparisons, Sweden stands out as a country in which the general transformation of values in the Western world from traditional-religious values to secular-rational and individualistic values is most advanced (Pettersson 2000). Sweden has also undergone rapid development in computer-mediated communication (Nordicom $2007^{5}$ ). In 1995, 3 percent of the population had access to the Internet and less than a third to a computer. In 2006, 80 percent of all Swedes have access to the Internet and to computers, and three out of five use the Internet on a daily basis. Among Swedish teenagers about 90 percent have a computer of their own and access to the Internet via broadband. As a group largely distanced from traditional, organized religion, but highly connected to the Internet, Swedish youth provide an interesting case for studying the significance of the Internet as a new context for exploring religion.

Young people and their use of the Internet for exploring religion has been the topic of some earlier Swedish studies. Anders Sjöborg (2006) studied a website for information and discussions about the Bible set up in cooperation between Christian Churches. The study, which involves young people with varying degrees of previous experience of a Christian tradition, shows how they use the Internet in various ways to explore a traditional religious authority on their own terms. Other studies (Larsson 2003) have argued that the relative anonymity of computer-mediated communication makes it easier for young people to find alternative sources of information about religious beliefs and practices, pose questions to religious leaders or approach them in order to talk about problems and existential questions (Stenberg-Roos 2006). A central assumption in early discussions of 
religion on the Internet has been that because the Internet expands the range of religions that most individuals have access to in the local context, people would primarily look for alternatives to mainstream religions online. Case studies of young people drawn to new religious movements such as Wicca and Satanism (Lövheim 2004, Berger \& Ezzy 2004) show that the Internet not only provides access to information about these traditions, but is also supportive networks of likeminded individuals. This is also the case for young people belonging to newer religious traditions in Swedish society, such as Islam (Schmidt 1999). However, interviews with and observations of young people who interact in discussion groups on religious sites as well as social networking sites show that this may also bring new challenges (Lövheim 2004, 2007). The format of short, written contributions and the high inflow of new participants seem to encourage polarized debates rather than open dialogue. Whether an individual can develop the kind of trust needed to use the possibilities of the Internet for his or her purposes is also structured by the discourse and social relations formed in a particular setting (ibid., see also Lövheim \& Linderman 2003). This applies particularly to young women, while young men seemed to be more confident in using this kind of interaction.

In sum, previous Swedish case studies show some support for the expectations described earlier. The Internet gives young people several possibilities to approach religion beyond the organizational framework and to access information supplied by religious institutions and authorities, as well as to explore religion on their own terms alone or in networks of likeminded individuals. However, these studies also show that differences between young people with differing social and cultural backgrounds, including previous experience of religion, affect how they use these possibilities (cf. Lövheim \& Sjöborg 2007). Because most previous studies have been small case studies focused on certain religious groups or uses of explicitly religious sites, there is a need for studies set in a larger and more heterogeneous group of young people. The present study is the first online survey conducted on a site in which large numbers of young people with diverse backgrounds meet, and which is not set up by a religious organization or oriented toward religion as such. Thus, the study provides a good possibility to discuss some indications, found in previous research, concerning the significance of the Internet for religion, and especially young people's relation to it.

\section{The Study}

The present findings are based on an online survey conducted in April 2007 on the Swedish-speaking web community LunarStorm (www.lunarstorm.se). During the first part of 2007, the site had 1,200,000 individual members and 363,300 unique visitors daily. At that time, LunarStorm was the largest social networking site for teens in the Nordic countries. LunarStorm provides members with a range of functions such as a personal webpage, chat, discussion groups and clubs. Among these were several focused on religion, faith and philosophies of life.

The total of 540,000 members are between 15-20 years of age. This represents almost two-thirds of the age group in the Swedish population ${ }^{6}$. The study consisted of an online survey directed to members of LunarStorm in this age group. The survey was distributed to a random sample of this population through LunarStorm's internal e-mail system "Lunarmejl". The respondents had seven days to answer the questions. A total of 1100 individuals answered the survey ${ }^{7}$. The survey consisted of eight questions based 
on assumptions and indications from the previous research outlined above. These will be presented in more detail together with the results in the next section.

\section{Age, Gender and Religion}

Of the 1100 individuals who answered the survey, 49.3 percent were women and 50.7 men. The mean age of the respondents was 16.8 years. Compared to LunarStorm's members between 15-20 years, the distribution of respondent age is in accordance with the normal distribution, but there is a slight overrepresentation of men in our sample ${ }^{8}$.

The first four questions focused on the religious profile of the young people participating in the survey. When asked about their beliefs in God, the largest group chose the alternative "I do not believe in any form of God or supernatural power". Together with those who chose the alternative "I do not know what I believe", they make up the majority of the responses: 56 percent. Less than a fourth of respondents chose alternatives in line with traditional religious teachings about God, such as belief in a transcendent God or a personal God ("a God that exists within each individual"). When asked about how they would describe their own religiosity, the largest group, 42 percent, chose the alternative "I believe in my personal way". Almost a third or 27 percent described themselves as Christians, but not more than 4 percent as Muslims and only 1 percent as Buddhists9. Around 10 percent used the possibility to describe their religiosity in their own words, and among those around 3 percent described themselves as Satanists or Neopagans. Fifteen percent described themselves as atheists. When comparing these questions, we see that in most cases, the answers follow a pattern, in which self-described religiosity matches beliefs in God. Thus, most of the respondents believed in their own personal way and were uncertain about their beliefs about God or believed in a more general supernatural or spiritual power. Because the groups of Muslims, Buddhists and new religious movements were too small for a meaningful separate analysis, in the coming analysis they will in most cases be combined into one group of "other religions", which then make up a total of 16 percent.

Findings from previous studies show that there are several reasons for focusing particularly on differences between young people who participate in organized religion and those who do not. In Sjöborg's study of a website particularly aimed at discussions of the Bible, more than two-thirds of users were members of religious youth organizations and at least half of the respondents took part in services as often as once a month (Sjöborg 2006:120). In the present study, 15 percent of the respondents took part in organized religious activities such as youth programs or services as often as once a month. The majority of these individuals (61 percent) described themselves as Christians and believed in either a personal, inner God or a transcendent God. 12 percent described themselves as Muslims, Buddhists or Jews. It is a common pattern in studies of young people and religion that women are more active in organized activities than men are. However, in the present study, the number of men and women who reported being active in organized religion was not different from the sample in general - which implies a slight overrepresentation of men.

We have no figures on the rate of participation in organized religion among the population of members of LunarStorm in the age group under study. A survey based on a representative sample of the population of young people between 16-29 years (Ungdomsstyrelsen 2007:270) showed that around 5 percent take part in religious meetings at least once a month. Participation in confirmation classes is also higher in the sample, 
40 percent, than the numbers for all 15-year-olds in Sweden, which in 2006 was 35.6 percent ${ }^{10}$. Thus, we may conclude that the young people in the present study who were active in religious organizations outside the Internet represented a minority of the sample, and that they also held beliefs closer to traditional religious beliefs than did the rest of the respondents. This group seems to be larger in the sample than among Swedish teenagers in general, but smaller than users of a more explicitly religious website in the same age group. The majority of the respondents, 85 percent, reported not being as active in organized religion, and most of them described themselves as believers in their own personal way or as atheists.

\section{The Internet as a Context for Exploring Religion}

In the survey, we wanted to know how young people value the Internet as a context for exploring issues of faith and religion in relation to other contexts in their everyday life, outside of organized religion. The question was: "In which of the following contexts have you encountered questions about faith and religion during the past 12 months?" The chart below shows what percentage of respondents chose the different alternatives given. More than one alternative could be chosen ${ }^{11}$. About one-fourth or 25 percent of respondents chose the alternative "I don't know". These are not shown in the chart below, but this figure is important to keep in mind, as it indicates that a significant group of young people may not come into contact with religion in their everyday life through any of the options given.

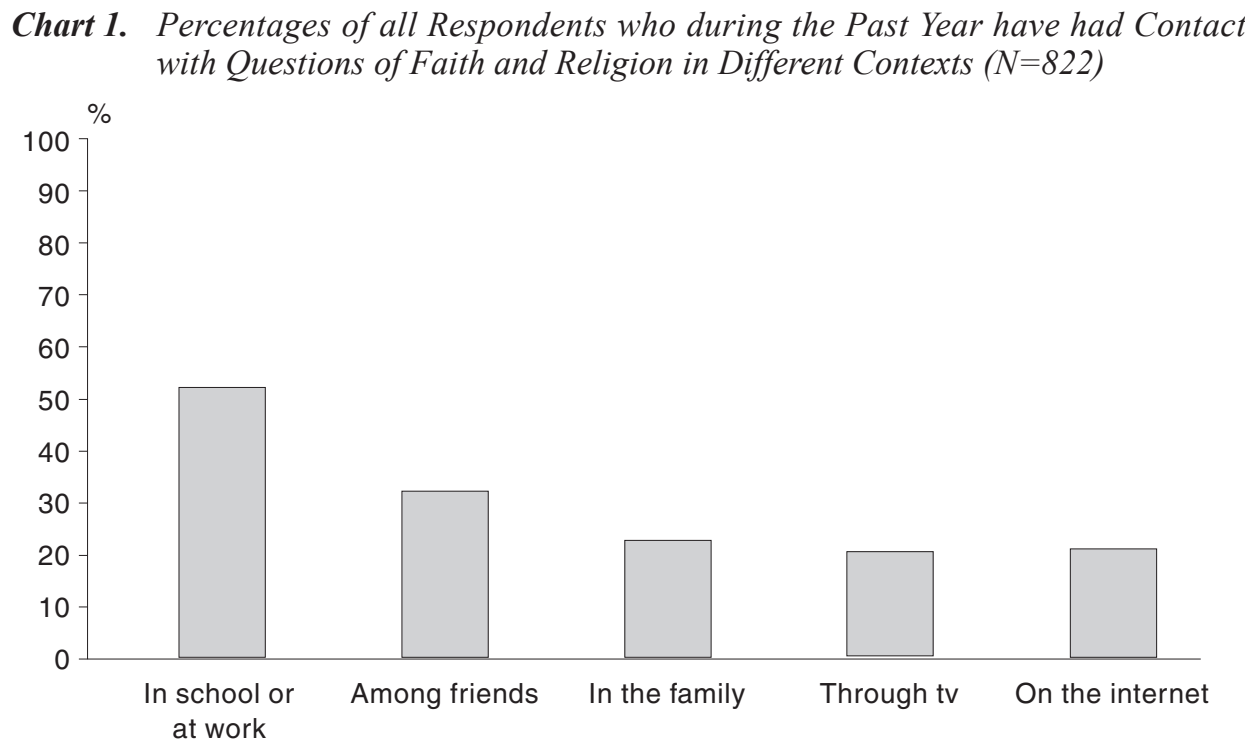

The responses show that the context in which Swedish teenagers most often come into contact with religion is in school (52 percent), and among friends (33 percent), while around 20 percent have encountered religion via the Internet, and an almost equal amount through television. Thirty percent responded that they have come into contact with religion through the Internet and television. The proportion of young people who say they encountered religion in the family is 23 percent. There are also differences in the groups of young people that come into contact with religion via the Internet. When 
we compare ${ }^{12}$ the responses of the different groups described earlier, we see that young people who are active in religious organizations are more likely to report that they have encountered religion in the family, among friends and via the Internet. Also, young men seem to have had more experiences of religion online than young women have.

\section{Using the Internet for Religious Purposes}

As a platform for computer-mediated communication, the Internet offers several applications for exploring religion. On the basis of previous research, nine different alternatives were listed, and respondents were asked to estimate how often they used these ${ }^{13}$. Responses for each of the listed alternatives show clearly that the majority of respondents reported never having used this application. Therefore, percentages for individuals who said they use these functions a few times a year or more frequently have been combined in the chart below to provide an overview of the results.

Chart 2. Percentages of Respondents who have Used the Internet for Religious Purposes a Few Times a Year or More (N varies between 1073-100)

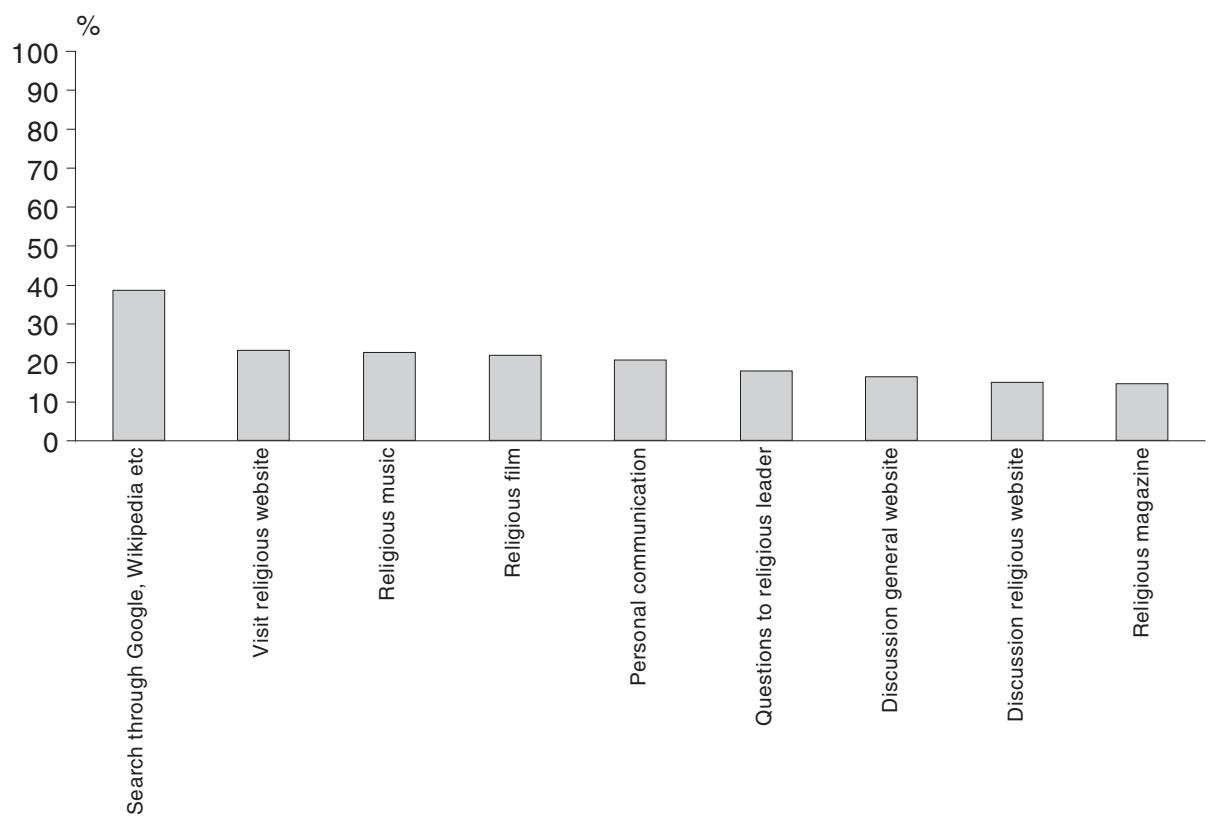

This chart shows that the most frequent use of the Internet for religious purposes for all respondents is to use web browsers or encyclopedia sites to find information; 38.5 percent use this function at least a few times a year. Seeking information by visiting a religious website is less common; about 23 percent say they have done so. About 20 percent reported looking for religious music or film online. Seeking information and seeking religious entertainment on the Internet, thus, seem to be the most popular activities, while forms of social interaction are less popular. Here, the respondents seem to use personal communication slightly more than more public forms of discussion in groups. Twenty-one percent reported having had experience of personal communication through e-mail, MSN messenger or similar forms of communication, while a total of 19 percent have had experience of discussing religion in a group or chat. A closer analysis of these 
respondents shows that the majority, almost two-thirds, reported discussing religion in both of the contexts given as alternatives. However, as the chart above shows, most of them discussed religion in groups provided by sites with a more general character, such as LunarStorm, while a smaller group used groups at explicitly religious sites.

When we compare different groups in the sample, it is, first of all, clear that young people active in organized religion reported using all of these alternatives more frequently than did those who are not as active (cf. Sjöborg 2006:131). The largest difference between the groups concerns activities that are more explicitly related to religious organizations or representatives. While more than 50 percent of those actively involved in religion offline have posed questions to religious leaders, visited religious websites or looked for religious music and film, less than 20 percent of young people who are not active in religious organizations have visited religious websites, or looked for religious music, magazines and films. About 12 percent of those who are not active have posed questions to religious leaders, and less than 11 percent have taken part in discussion groups at religious websites or read religious magazines.

Differences in self-described religiosity are small and somewhat difficult to read. However, it seems clear that Christians reported using all alternatives more frequently than others did, but most frequently religious websites, music and film as well as posing questions to religious leaders. The group that seem to use discussion groups as well as personal communication more frequently than others is the somewhat awkward category of "other religions", including among others Muslims, Satanists and Neopagans. Also the atheists reported using discussion groups at websites of a general character or personal communication more frequently than others did. Finally, those who believed in their own personal way seem to look for religious films and pose questions to religious leaders most frequently. The only difference related to gender seems to be that young men use discussion groups on religious websites more frequently than young women do.

The survey contained no questions about uses of the Internet for other purposes than religion. Studies of Internet use in a representative sample of the population (Nordicom 2007) show that the most frequently used activities in the age group closest to our sample, 15-24 years of age, are e-mail (54 percent), participation in chat or discussion groups (53 percent), looking for information (37 percent), listening to music (20 percent) and playing games (18 percent). Thus, some of the most frequently used options in our sample, such as information seeking and use of music and film, seem to correspond to young people's habits of Internet use in a more general sense. The most obvious exception is social interaction in the form of discussions or personal communication through e-mail, where young people in the sample seem to use these less frequently for religion than they do for other purposes.

As described in the introduction, one assumption about the Internet has been that it gives access to a wider range of religions than what is available in most local contexts. Therefore we asked about what kind of religion young people look for online. The responses show that the religion respondents looked for most frequently was Christianity: More than 36 percent did so at least a few times a year. About 30 percent also looked for information about the other major world religions: Islam, Hinduism, Buddhism and Judaism. Thus, new or alternative religious movements seem to be less popular than expected. Most popular was Satanism, which more than 25 percent reported looking for online a few times a year. When comparing different groups we can, again, see that it is the group of respondents active in organized religion that most frequently look for 
information about all kinds of religion online. It also seems as if they mostly look for information similar to their own religious beliefs.

\section{Why Use the Internet for Religious Purposes?}

The final question concerned reasons for using the Internet for exploring religion. On the basis of previous studies in Sweden, we would expect to find differences between young people with regard to involvement in religious organizations offline, self-described religiosity and gender. Here, a number of alternatives based on indications found in previous research were presented. The respondents were asked to state whether they agreed with these reasons. In the analysis below, only the percentages of those who responded that they agreed strongly with the statement will be displayed ${ }^{14}$. When looking at the whole group, it is clear that the reason most of the respondents agree with concerns uses "for school or work". More than half of the respondents, 55 percent, chose this alternative. The next two alternatives, with which more than 10 percent agreed strongly, were "for personal development" (13.4 percent) and "to encounter opinions other than my own" (11.6 percent). The pattern showing that these three reasons seem most in line with respondent's experiences is similar for all groups regardless of involvement in organized religion, religiosity or gender. As can be seen in the chart below, young people who are actively involved in organized religion agreed to a larger extent with all of the given alternatives than did those who are not active. We can also see some between-group differences in the reasons given.

Chart 3. Percentages of Respondents Active and Not Active in Organized Religion who Strongly Agree with Reasons for Using the Internet for Religious Purposes (N varies between $998^{15}-1016$ )

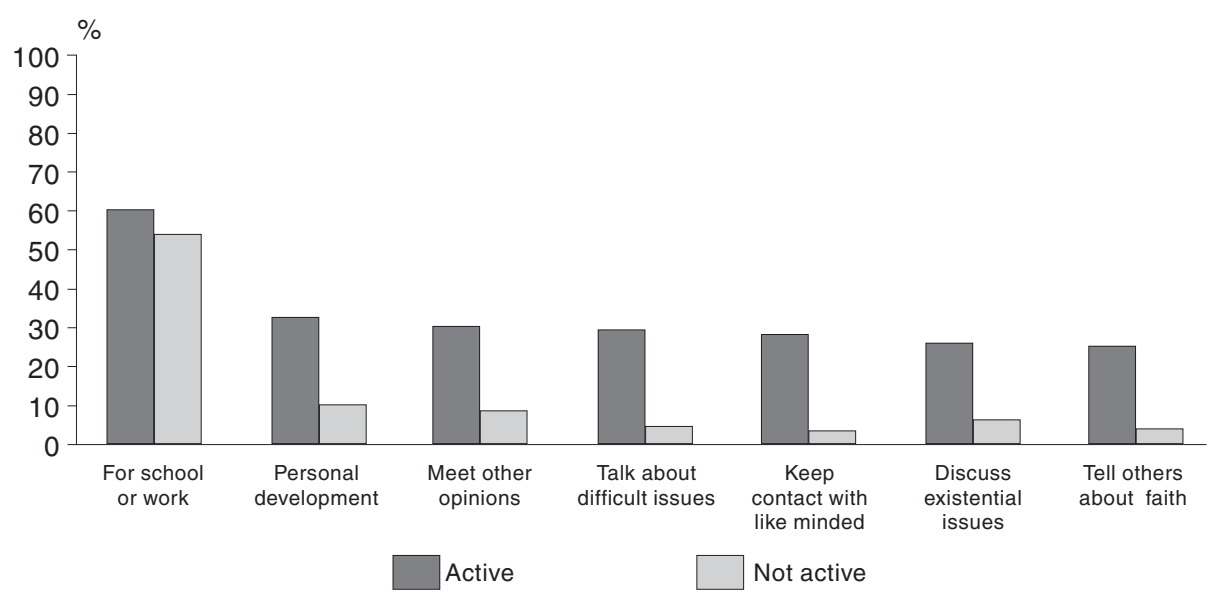

It seems as though the group of respondents who are active in religious organizations use the Internet to find someone to talk to about difficult issues in life, to tell others about their faith and to maintain contacts with likeminded individuals to a greater extent than do those who are not active. The latter group seems to use the Internet to discuss existential issues rather than to talk about their problems, their faith or to seek out the company of likeminded individuals. There are also some differences between men and women. Men seem to agree more strongly than women do with reasons concerning personal development, telling others about faith and maintaining contacts with likeminded 
individuals, while women tend to stress reasons of school or work. Finally, the responses also show some differences between individuals who described their religiosity in different ways. These differences are small, but they indicate some interesting patterns: For those who described themselves as Christians, maintaining contact with fellow believers, sharing their faith with others and finding someone to talk to about difficult issues are the reasons most agreed with, while discussing existential issues and school seem to be less valued. This pattern is somewhat similar to the group of "other religions" (Muslims, Buddhists, Satanists, Neopagans), except that these respondents placed more value on the possibility of encountering opinions other than their own. The largest group, those who reported believing in their own personal way, seem to use the Internet primarily for reasons that have to do with school, personal development and discussing difficult and existential issues.

\section{Rethinking Cyberreligion?}

Since the advent of the Internet, expectations about its implications for the future of religion have been high, not least within religious denominations. Swedish teenagers are among the most active users of the Internet in the world, but does this also imply that they will embrace the Internet as a new arena for exploring religion? Although previous studies have indicated this potential, the findings of the present study challenge, in several respects, early expectations of the significance of the Internet as a new arena for religion in contemporary society. In this final part I will, first, summarize the findings of the study and relate these to some of the assumptions and indications outlined in the introduction. Second, I will point out some ways in which these findings can contribute to a discussion on future research in the area of young people, religion and the Internet.

\section{Results of the Study}

The findings of the survey presented here show that about 20 percent of the respondents have encountered religion and about 40 percent have looked for information about religion on the Internet at least once a year. A survey distributed among a representative sample of the Swedish population in February 2007 (Linderman 2007) shows a similar percentage of respondents between 15-23 years who have had contacts with religion on the Internet. This survey also reveals significant differences concerning such contacts between younger and older generations. While almost 20 percent of the young chose this alternative, only 7 percent in the total sample did so. As we have seen, other studies have shown that about 5 percent of Swedish teens visit organized religions at least once a year. In so far as these findings reflect general patterns among Swedish teenagers, then more young people do seem to come into contact with religion via the Internet than through local religious communities. However, the present study clearly shows that researchers need to be careful in drawing conclusions about the significance of the Internet for young people's relation to religion based on such results. The present findings also show that, for the majority of respondents, the Internet is not the context in which they primarily come into contact with religion. Although Swedish teenagers spend considerable time online daily, school and friends are still the primary contexts for encountering religion in everyday life.

A majority of the survey respondents were not affiliated with organized religions, nor did they share the beliefs of these. Most of these young people had not had contacts with 
religion on the Internet, nor had they used the Internet for any of the purposes listed. Thus, the present study gives little support to expectations that the Internet can be a way for organized religions to reach out to new groups. Instead, the findings in several ways support the results of the Pew report "Faith Online" (Hoover, Clark \& Rainie 2004). Also among teenagers in Sweden, the Internet seems to be a significant context for exploring religion particularly for the "offline faithful". Young people who are active in organized religion outside the Internet, who describe themselves as Christians and whose belief in God is in correspondence with the teachings of the Church form a clear minority of the respondents in the present study. Yet this group contains by far the most frequent users of religious websites and discussion groups as well as religious music, films and magazines.

The group of respondents already involved in organized religion, and in particular the Christians, also stressed the possibility to keep in contact with likeminded individuals, to pose questions to religious leaders and to find someone to talk to about difficult issues in life more than the other groups did. Thus, the present results support the argument made by, among others, Campbell (2005) that, for individuals actively involved in offline religious life, faith-related activities online are a complement to rather than a substitute for organized religion. As argued by Hoover, Clark and Rainie (2004:ii), the Internet does provide access to resources outside formal religious contexts. However, these resources seem to be primarily of a kind that augments already strong commitments to people with whom these individuals share their faith offline. Also, it seems that the relative anonymity of interaction online may not in itself be enough for young people to approach religious groups or representatives when facing difficult questions about meaning, life and death. Some previous experience of religion seems to be needed to initiate such contacts.

The present survey shows clearly that most of the respondents used the Internet to look for information about religion through Google, Wikipedia or similar search engines or encyclopedia sites. The reason for using the Internet to explore religion that most of the respondents agreed with was "for school or work". One may argue that this finding is self-evident, given that schoolwork takes up a large part of young people's everyday lives. Nevertheless, it shows that researchers should be careful in interpreting the number of visits to religious websites as a growing personal interest in religion. The 13 percent in the study who chose the alternative "for personal development" does show that some young people seem to have such intentions. However, even in this case, we cannot conclude that the interest concerns the beliefs and practices of religious institutions. These findings rather point to a pattern in which religion on the Internet is more frequently used as a resource for purposes that relate to the individual and the personal concerns of everyday life, than for purposes that relate to social interaction within a religious community. The study shows clearly that discussion about religion in groups is much less popular among young people of all religious backgrounds, while searching for religious information, film, music and personal communication occur more frequently. Also in the Pew report, the most frequent uses of the Internet for "religious purposes", such as exchanging e-mail with religious or spiritual content and online greeting cards, relate to individual faith or at least social interaction in ways other than those traditionally offered by religious institutions.

The present findings show that those respondents who described themselves as Muslims, Buddhists, Satanists, Neopagans or atheists are somewhat more interested than others in using discussion groups. These respondents are, of course, different in many ways, but they share the experience of being seen as marginal groups in a society histo- 
rically dominated by the major Lutheran religious institutions. Thus, these findings give some support to the indications found in previous research that young people in religious minorities can find access to alternative sources of information and form supportive networks of likeminded via the Internet. An interesting issue for further research is how such sites may come to serve as religious subcultures for these youth. However, we need more studies in order to draw further conclusions about such tendencies.

Finally, it is interesting to note that while the majority of the "online faithful" in earlier studies (Hoover, Clark \& Rainie 2004, Sjöborg 2006) were women, the present study shows that young men seem to be more actively engaged in exploring religion on the Internet than young women are. The results show significant differences between men and women, particularly concerning the use of discussion groups, and telling other people about their faith. This corresponds to earlier Swedish case studies, where young men seemed more at ease with using public forms of discussion online than young women did (Lövheim 2004). Also, young men seem to value the possibility to find someone to talk to about difficult events in life more than women do. Thus, these findings indicate that if the organized religions can hope to reach any "new" groups through the Internet, such groups might be young men, who in most offline contexts form a minority.

\section{Concluding Discussion}

In a review of the first decade of research about religion on the Internet, Lorne Dawson and Douglas Cowan called for reconsideration of early assumptions that the Internet per se is transforming religion (Dawson \& Cowan 2004:6, cf. Højsgaard 2005:62). The present findings support this conclusion. Furthermore, previous research has primarily focused on specific religious groups or sites and on individuals who actively take part in activities connected to these, which may have contributed to an over-estimation of the significance of the Internet for religion. One fruitful approach for further research would be to situate research about religion online in the wider discussion of general transformations of religion in contemporary society, as well as research about the impact of the Internet on other areas of social life. I will end by pointing to two issues in relation to which the findings of the present study can contribute to a more refined discussion.

The first issue concerns how to evaluate the significance of the Internet for young people's experiences of religion. It may be tempting to interpret the present results as showing signs of a resurgence of religion on the Internet. In line with the argument that young people's attitudes and habits are predecessors of future trends in society (Ingelhart 1977), these findings suggest that the Internet will become a significant context for religion in the future. However, I would argue that rather than interpreting these findings as signs of a religious resurgence among young people, they show how traditional contexts for religious socialization, such as the Church or the family, are gradually being replaced by other contexts. The findings also indicate that mediated experiences of religion, here primarily via the Internet and television, may be almost as common as contacts with religion through friends. Thus, the media are an important part of this process, but we need further studies of the meaning of this transformation. Here, the findings also show that how young people make meaning of what they encounter in the media needs to be analyzed within the contexts given by the conditions and patterns of social interaction in the schools as well as in peer groups. Thus, by comparing the Internet and other contexts in which people encounter religion in contemporary society, we can gain a better understanding of how the Internet contributes to this development. 
The second issue concerns how young people approach religion in contemporary society. Hoover, Clark and Rainie (2004:20) argued that the most significant impact of the Internet lies in augmenting a development in which individuals come to exercise more autonomy in relation to formal authorities and institutions in matters of faith. The study presented here also shows that young people's contacts with religion on the Internet primarily concern individual needs and interests. Overall, only a minority had experience of several of the activities and purposes given as alternatives. Thus, the present results call for reconsideration of the purpose for which people look for religion online. They also reveal how little we know about if and when religion becomes actualized in young people's uses of the Internet. One area in which this comes to the fore concerns why young people do not seem to use e-mail, chat or discussion groups, which they generally use frequently, for issues related to religion. This result corresponds to the tendency for religion to become more of a personal than a social matter, but it may also be a consequence of the questions used in the survey. Contrary to the assumptions of several earlier studies, the social contexts of interaction on the Internet do not seem to be religious discussion groups or e-mail lists. Lynn Schofield Clark (2004) argued for an approach to religion online that starts out from how new technologies become interwoven with the off-line, socially oriented meaning making practices of young people. The present study suggests that such practices can take place by sharing sources of information for schoolwork, music and films, the concerns of everyday life or by making connections across personal networks. These practices can also show where future research needs to be directed if we are to understand more about when and how issues of meaning, belonging, life and death, previously expressed in religious words and ritual, become actualized in young people's experiences online.

\section{Notes}

1. Paper originally presented at the NordMedia 2007 Conference 16-19 August 2007 in Helsinki, Finland by the author.

2. The study was based on telephone interviews with a sample of the American population aged 18 and older. The findings reported here are based on Internet users (1358 individuals out of a total of 2013 individuals).

3. 38 percent had sent and received e-mail with religious or spiritual content, 35 percent had exchanged online greeting cards and 32 percent read news accounts of religious events and affairs.

4. Statistics retrieved from the Church of Sweden statistical database (http://www.svenskakyrkan.se/statistik/, July 7 2007).

5. Nordicom-Sveriges Internetbarometer is a yearly study based on telephone interviews with a random sample of the Swedish population between 9-79 years of age.

6. It is, however, important to point out that the sample analyzed here should not be seen as representative of the Swedish population in the age group 15-20.

7. Surveys at LunarStorm are conducted by the administrators of the site. A survey is sent to a sample of approximately 2000 members and remains open until a requested number of responses, usually 1100, is reached. Thus, it is not possible to know the exact response rate. The number of participants, however, enables calculations of levels of significance for different groups. For all results reported here, $\mathrm{p}$ is lower than or equal to 0.05 (i.e. the probability of these differences being random is less than 5 percent).

8. The mean age of members is 18.1 years and the distribution of gender among members $15-20$ years is 53 percent women and 47 men (www.lunarworks.se). LunarStorms statistics give no information about ethnicity or social background.

9. 4 persons also chose the alternatives Hindu or Jew.

10. www.svenskakyrkan.se/statistik 2007-07-10.

11. A closer analysis shows that the largest group of respondents, 41 percent, has chosen one alternative while 25 percent chose 2-3 alternatives, and 11 percent 4 to 5 alternatives. The majority of those who responded that they had three or more contexts for contact with religion were active in organized religion. 
12. Comparisons made using cross tables and chi-square tests as well as Mann Whitney U-test (for gender and activity) or Kruskal-Wallis test (mean ranks, for categories of self-described religiosity).

13. The alternatives given were "every day", "at least once a week", "at least once a month", "a few times a year" and "never".

14. The alternatives were "agree totally", "agree to a large extent", "either/or", "agree to some extent" and "do not agree". These have been combined into three categories, where the first two form the category of respondents who agree strongly.

15. The lowest rate of responses is for the alternative "To tell others about my faith" (n=998).

\section{References}

Berger, H. \& Douglas, E. (2004) 'The Internet as Virtual Spiritual Community. Teen Witches in the United States and Australia', in Dawson, L.L. \& Cowan, D.E. (eds.) Religion Online: Finding Faith on the Internet. New York, NY: Routledge.

Campbell, H. (2006) 'Religion and the Internet', Communication Research Trends. 1(25): 3-18.

Campbell, H. (2005) Exploring Religious Community Online. We are One in the Network. New York, NY: Peter Lang.

Clark, L.S. (2004) 'Spirituality Online. Teen Friendship Circles and the Internet', Paper to the 4th International Conference on Media, Religion and Culture, Louisville, KY.

Dawson, L.L. \& D.E Cowan (2004) (eds.) Religion Online: Finding Faith on the Internet. New York, NY: Routledge.

Hadden, J. \& D.E Cowan (2000) (eds.) Religion on the Internet: Research Prospects and Promises. Amsterdam, London \& New York: JAI Press.

Hoover, S.M., Clark, L.S. \& Rainie, L (2004) Faith Online. Report from Pew Internet \& American Life Project, www.pewinternet.org, Nov 6, 2006.

Højsgaard, M.T (2005) 'Cyber-religion: On the Cutting Edge between the Virtual and the Real', in Højsgaard, M.T. \& Warburg, M. (eds.) Religion and Cyberspace. London: Routledge.

Ingelhart, R. (1977) The Silent Revolution. Changing Values and Political Styles in Western Publics. Princeton: Princeton University Press.

Larsson, G (2003) 'Att vara ung och muslim i Sverige' [Being young and Muslim in Sweden], in Larsson, G (ed.) Talande tro. Ungdomar, religion och identitet. Lund: Studentlitteratur.

Linderman, A.G. (2007) 'Religion and the Media - An Audience Perspective', paper to the $18^{\text {th }}$ Nordic Conference for Media and Communication Research, Helsinki.

Lövheim, M. \& Sjöborg, A. (2007) 'Unga och tro på nätet' [Youth and Belief on the Internet], in Lindgren, S \& Sandgren, T (eds) Unga och nätverkskulturer - mellan moralpanik och teknikromantik. Ungdomsstyrelsens skrifter 2007:17.

Lövheim, M (2007) 'Virtually Boundless? Youth Negotiating Tradition in Cyberspace', in Ammerman, N.T. (ed.) Everyday Religion. Observing Modern Religious Lives. Oxford, NY: Oxford University Press.

Lövheim, M (2004) Intersecting Identities. Young People, Religion, and Interaction on the Internet. Sociology of Religion, Dept of Theology. Uppsala: Uppsala University. (Diss.)

Linderman, A.G. \& Lövheim, M. (2003) 'Internet, Religion and the Attribution of Social Trust', in Mitchell, J. \& Marriage S. (eds.), Mediating Religion: Conversations in Media, Religion and Culture. Edinburgh, London \& New York: T\&T Clark/Continuum.

Nordicom-Sveriges Internetbarometer 2006 (2007). Released at www.nordicom.gu.se 2007-08-15.

Pettersson, T. (2000) 'Svensken och religionen' [The Swedes and religion], in Lewin L. (ed.) Svenskt kynne. Skrifter utgivna av Statsvetenskapliga föreningen 139. Uppsala: Acta Universitatis Upsaliensis.

Schmidt, G. (1999) 'Sveriges Förenade CyberMuslimer - blågul islam på internet?' [Sweden's united cybermuslims - blue and yellow Islam on the internet?], in Svanberg, I \& Westerlund D. (eds.) Blågul islam? Muslimer $i$ Sverige. Nora: Nya Doxa.

Smith, C. with Lundquist Denton, M. (2005) Soul Searching. The Religions and Spiritual Lives of American Teenagers. New York, NJ: Oxford University Press.

Sjöborg, A. (2006) Bibeln på mina egna villkor. En studie av medierade kontakter med bibeln med särskilt avseende på ungdomar och internet [The Bible on my own terms. A study of mediated contacts with the bible with special regard to youth and the Internet]. Uppsala: Acta Universitatis Upsaliensis. Psychologia et Sociologia Religionum 18 (Diss).

Stenberg-Roos, E. (2006) 'Själavård på nätet' [Spiritual counseling online], in Larsson, G. , Lövheim, M. \& Linderman, A.G. (eds.) Religion och medier: några perspektiv. Lund: Studentlitteratur

Ungdomsstyrelsen (2007) Unga med attityd. Ungdomsstyrelsens attityd och värderingsstudie 2007 [Youth with an attitude. Attitude and values survey for the Swedish national board for youth affairs]. Ungdomsstyrelsens skrifter 2007:11. 